\title{
Ultra friss osteochondralis allograft átültetéssel szerzett 10 éves
} magyarországi tapasztalataink

\author{
DR. HANGODY LÁSZLÓ RUDOLF, DR. VÁSÁRHELYI GÁBOR, \\ DR. TÓTH FERENC, DR. HANGODY LÁSZLÓ
}

\section{ÖSSZEFOGLALÁS}

A mély, nagy kiterjedésú osteochondralis defektusok kezelése továbbra is kihívást jelent az ortopédtraumatológus számára. A friss osteochondralis allograft átültetés széles spektrumban alkalmazható technika, és szinte az egyetlen lehetőség masszív osteochondralis laesiók kezelésére, különösen fiatal életkorban. Az utóbbi néhány évtizedben, a nemzetközi irodalomban kiterjedt kísérletes, de világviszonylatban sporadikus klinikai tapasztalat gyúlt össze az eljárást illetően. A technika hazai bevezetése óta a graft elérhetőség terén jelentős javulás történt, azonban az átültetés logisztikai nehézségei, az átültetett graft méretezése és befogadó helyre történő illesztése, valamint a heterogén beteganyagból fakadó individuális utókezelés továbbra sem egyszerű e módszer kapcsán. Jelen cikk áttekinti az eljárás történelmi fejlődését és összegzi a technika legfontosabb kísérletes és klinikai vonatkozásait. A szerzők ismertetik saját kísérletes eredményeiket, fejlesztéseiket és a friss osteochondralis allograftok átültetésével szerzett 10 éves klinikai tapasztalataikat több ízület vonatkozásában is.

\section{Kulcsszavak: \\ Chondrocyta; Csont-transzplantáció; Donor elérhetöség; Graftok; Porcátültetés;} Transzplantáció, homológ;

L. R. Hangody, G. Vásárhelyi, F. Tóth, L. Hangody: Cartilage repair with ultra fresh osteochondral allografts: evaluation of 10 years Hungarian experience

Treatment of extended and massive osteochondral defects is a real challenge for the orthopaedic practice. Fresh osteochondral allograft transplantation is a technique wich is usable in wide spectrum, especially for such lesions in young age. Transplantation of osteochondral allografts has had extended experimental but limited clinical experiences during the recent decades. Regarding the Hungarian fresh osteochondral allograft transplantation practice, graft availability is much better than few years ago, but sizing, technical issues and different rehabilitation protocols represent still problematic points. This paper provides a historical perspective and summarizes the most important experimental and clinical details of a present approach to this therapeutical option. Authors also describe their experimental results and clinical experiences in 3 different joints during the last 10 years in Hungarian practice.

Keywords: $\quad$ Bone transplantation - Methods; Cartilage, articular - Transplantation;

Chondrocytes - Transplantation; Graft survival; Tissue donors;

Transplantation, homologous; 


\section{BEVEZETÉS}

Az osteochondralis allograft (OCA) átültetés már több mint 100 éves múlttal rendelkező eljárás a végtagsebészetben. A XX. század elejének egyik vezető sebész professzora, a német Erich Lexer már 1908-ban megkísérelt osteochondralis allograftot átültetetni, arckoponyai és alsó végtagi támasztószöveti defektusok pótlása céljából (15). Ez volt az első publikált kísérlet az eljárást illetően, amely értelemszerúen - az adott kor szerény mikrobiológiai és immunológiai ismereteinek megfelelően - nem végződött jó eredménnyel.

Az 1970-es években került e téma ismét előtérbe az Amerikai Egyesült Államokban, és azóta - a megnövekedett klinikai érdeklődésnek és tudományos kutatásoknak köszönhetően - reneszánszát éli (6). Az ekkor megjelent publikációk friss-fagyasztott, illetve fagyasztott és konzervált („cryopreserved”) OCA-k vizsgálatairól számolnak be $(20,21$, 27). Ezek a fizikai és kémiai eljárások kedvezőtlenül befolyásolják a chondrocyták hosszú távú túlélését. A fagyasztás ugyan megnöveli a graftok eltarthatóságát, emellett azonban az ízületi porcban megtalálható élő chondrocyták több mint 95\%-át elpusztítja (20). Ezen felül, a klinikai tapasztalat azt mutatta, hogy a hyalinporcban lévő sejtmentes mátrix a fagyasztott graftokban az idő előrehaladtával degenerálódik, valószínúleg azért, mert a minimális számú túlélő sejt nem képes fenntartani a szöveti homeosztázist (7). Az úgynevezett „cryopreserved" graftok esetében a fagyasztás valamilyen nutritív médiumban történik, ez valamelyest javítja a chondrocyták túlélését, azonban a sejtelhalás ilyen előkezelés mellett is drasztikus mértékű marad $(5,12,17)$. Ezért az ily módon tartósított és előkezelt graftok nem hozták meg a várt eredményt.

A friss OCA-k átültetésének alapkoncepciója az, hogy olyan érett, csontos alappal rendelkező hyalinporcot ültetünk át, ami metabolikus aktivitását, és kollagén mátrixát megtartva - a hipotermikus (vagy izotermikus) tárolást túléli. A hyalinporc olyan tulajdonságokkal rendelkező szövet, amely transzplantációra ideális. Elsősorban azért, mert - tekintve, hogy avascularis szövet - nem igényel vérellátást, metabolikus igényeit a synovialis folyadék felől, diffúzió útján elégíti ki. Másodsorban, mivel aneuralis struktúra, beidegzés nem szükséges a múködéséhez. Harmadrészt, az ízületi porc immunológiai szempontból semlegesnek tekinthető, hiszen a chondrocyták a sejtmentes mátrixba ágyazottan szinte teljesen rejtve maradnak a recipiens immunrendszere elől (14). Az OCA-k másik fő komponense a csontos bázis. Ez biztosítja a graft rögzítését és beépülését a befogadó oldalra. Ez a struktúra az átépülés során vázszerkezeti - úgynevezett scaffold - funkciót tölt be, és tekintettel arra, hogy eredetileg vascularizált szövet, a benne maradt vérsejtek a recipiens immunválaszát válthatják ki (24).

A friss OCA átültetés eredményessége a helyesen megválasztott betegpopulációban jól dokumentált a nemzetközi irodalomban. Számos szerző számol be sikeres közép- és hosszú távú eredményekről ezen graftok használata kapcsán. E közleményekből az derül ki, hogy a hosszabb távon is sikeres OCA átültetés „gold standard”-ja a friss, 4 Celsius fokon tárolt osteochondralis szövetek - nutritív médium használata mellett legfeljebb 28 napon belüli - transzplantációja. Ezek az oltványok a stabil csontos alapnak és a felszínen túlélő hyalin porcnak köszönhetően akár 25 évig is képesek túlélni és funkcionálni (11), tekintve, hogy ezek a graftok nagyarányú élő chondrocytát tartalmaznak, amelyek képesek fenntartani az extracellularis mátrix mechanikai tulajdonságait, sok évvel a beültetés után is $(8,10)$. A graft tárolás körülményeit illetően egyes közlemények beszámolnak 37 Celsius fokon tárolt oltványok sikeres átültetéséről is, azonban ma úgy tűnik, ez rontja a chondrocyta túlélést a 4 Celsius fokos tároláshoz képest. A különféle tápoldatok használata javít a graftok eltarthatóságán, ezek ideális összetétele azonban továbbra sem egyértelmú (22).

Minden szerv- és szövetátültetés kapcsán megvan a veszélye a különböző fertőző ágensek átvitelének, a donorok megfelelő szúrővizsgálatainak ellenére is (25). Az USA-ban a donorok szúrése - akárcsak a graftvétel és a tárolás is - az American Association of Tissue Banks irányelvei szerint zajlik (1). Ez tartalmazza a donor részletes anamnézisét, szerológiai és bakteriológiai vizsgálatait. Habár a HIV, a hepatitis vírusok és egyéb patogén ágensek szerológiai vizsgálatai jelentős fejlődésen mentek keresztül, és biztonságosnak tekinthetőek; 
csekély, de mégis mérhető ezeknek a súlyos betegségeknek a transzmissziós kockázata. E kockázat számszerúsítésével kapcsolatban eddig viszonylag szerények az irodalmi közlések.

$\mathrm{Az}$ OCA-k immunológiai vonatkozásait szintén figyelembe kell venni. Igaz ugyan, hogy a chondrocyták az extracelluláris mátrixba való beágyazottságuk miatt rejtve vannak a recipiens immunrendszere elől (14); viszont az is igaz, hogy a jelenlegi klinikai gyakorlatban vércsoport és HLA (human leukocyta antigén) szerinti egyezés nincs a donor és a recipiens között, és ez különböző mértékű immunválaszt képes kiváltani, elsősorban a graft csontos részében megmaradó vér alakos elemeinek köszönhetően. Mégis, az ezzel foglalkozó tanulmányok következetesen azt mutatják, hogy a betegek immunrendszere általában jól tolerálja a beültetést, immunmediált patológiás elváltozás nem, vagy csak minimális mértékben detektálható $(13,19)$. Ennek valószínúsíthető mútéttechnikai alapja a szivacsos csontállomány makroszkópos sejtmentesítése különböző kimosási módszerekkel (pl. jet-lavage).

Észak-amerikai szerzők több évtizedes tapasztalata támasztja alá a módszer eredményességét $(16,23,27)$, és ott ez az eljárás olyannyira jól bevált, hogy a friss OCA-t nem csak nagy kiterjedésú, mély defektusok esetében, hanem felszínesebb laesiókra is alkalmazzák a fiatalabb betegpopulációban (3). Az osteochondralis allograftok alkalmazási területe elsősorban a térdízület, de sikerrel alkalmazzák őket a felső ugróízületben (10), és kevesebb indikációval ugyan, de a csípő- (18), és a vállízületben (4) is.

A mútéti indikációt tekintve a friss OCA átültetés elsősorban a nagyobb kiterjedésű osteochondralis defektusok megoldására alkalmas eljárás, amelyek orvoslására a sebész megítélése szerint más porcfelszínképző eljárások nem alkalmazhatók. A felszín nagyságának vonatkozásában megoszlanak az irodalmi ajánlások. Általában $6-8 \mathrm{~cm} 2$ defektus kiterjedés felett mindenképpen ajánlható az eljárás, de több szerző már 2-4 cm2 felett is indikálhatónak tarja a homológ transzplantációt. Az indikációs körbe tartoznak az olyan tiszta porckárosodások, amelyek mérete kontraindikációt jelent más eljárások alkalmazására, illetve azok az osteochondralis defektusok, amelyek csontérintettsége $6 \mathrm{~mm}$-nél nagyobb mélységű. A klinikai gyakorlatban az alábbi betegségek esetén alkalmazzák leggyakrabban a friss OCA átültetést: osteochondritis dissecans, osteonecrosis, valamint a térd periarticularis törései következtében kialakult poszttraumás defektusok. Ezeken kívül az eljárást alkalmazzák patellofemoralis destrukciók és arthrosis esetén, illetve az unikompartmentalis vagy multifokális poszttraumás és degeneratív tibiofemoralis arthrosisok bizonyos eseteiben $(9,11)$.

Az egyre inkább kedvező térdízületi tapasztalatok miatt az allograftokat sikerrel alkalmazzák a bokaízületben is. A leggyakoribb indikációk a következők: poszttraumás arthrosis a felső ugróízületben, a talus osteonecrosisa és az osteochondritis dissecans azon eseteiben, ahol egyéb porcfelszínképző eljárás nem alkalmazható.

A friss OCA beültetés életkori alkalmazhatóságát illetően megoszlanak a vélemények, korábban több szerző a 40-45 éves életkort ajánlotta felső korhatárnak, de ez az utóbbi évtizedben feljebb tolódott s nemrégiben 60 éves kor utáni sikeres beültetésekről is számoltak már be. Egységes álláspont az életkor vonatkozásában nem alakult ki (10).

Az amerikai centrumok OCA ellátását megfelelő szövetbanki háttér biztosítja. A módszer meghonosításának legnagyobb akadálya a friss OCA-t biztosító magyar szövetbank hiánya, azaz a megfelelő donorelérhetőség volt. Közleményünkben e probléma leküzdéséért tett lépéseinket, valamint friss OCA hazai átültetésével szerzett eddigi 10 éves klinikai tapasztalatunkat mutatjuk be térd-, felső ugró-, illetve radiocarpalis ízületek vonatkozásában.

\section{ANYAG ÉS MÓDSZER}

2008 és 2018 között 19 betegen végeztünk friss OCA átültetést (a módszer Magyarországon klinikai kísérletnek minősül, alkalmazására ETT-TUKEB engedélyt kaptunk). A beültetéseket három sebész végezte. Átültetéseink megoszlása: 13 térdízületi, 3 felső ugróízületi és 3 radiocarpalis ízületi transzplantáció.

Betegeink nemi megoszlása és átlagéletkora az átültetéskor: térdízület átültetés: összesen 13 beteg, ebből 8 férfi és 5 nő (átlagéletkor: 31,9 év), felső ugróízületi átültetés: 3 férfi (átlagéletkor: 57,7 év), radiocarpalis ízületi 
átültetés: 3 férfi (átlagéletkor: 37 év).

A 13 térdízületi transzplantációnk indikációs megoszlása: 4 poszttraumás, jelentős anyaghiánnyal járó osteochondralis defektus, 6 nagy kiterjedésű osteochondritis dissecans, 1 szteroid kezelés talaján kialakult osteochondronecrosis, 1 krónikus haemorrhagiás synovitis talaján kialakult laesio, illetve 1 elülső keresztszalag hiánya mellett kialakult osteochondralis defektus. Felső ugróízületi átültetésünk indikációja poszttraumás arthrosis volt (mint relatív indikáció), radiocarpalis átültetéseink indikációja mindhárom esetben poszttraumás, jelentős panaszt okozó radiocarpalis ízfelszín incongruentia volt.

Valamennyi friss OCA átültetésünket a donorszövet kivételét követően legkésőbb 48 órán belül elvégeztük (ultra friss beültetések). A donorszövetet a beültetésig 4 Celsius fokon tároltuk. Mind a donorszövet kivétele, mind a tárolás, illetve a beültetés is a sterilitási rendszabályok betartásával történt. A beültetések technikája attól függött, hogy a defektus elhelyezkedése és mérete milyen

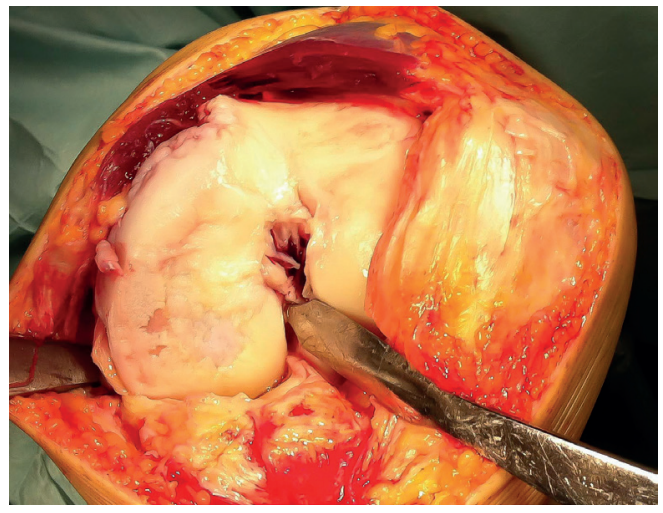

1. a ábra

Nagy kiterjedésü osteochondralis defektus a medialis femur condyluson (28 éves ffi beteg) volt. Azokban a térdízületi transzplantációkban, ahol az osteochondralis defektus nem érintette a femur condylus szélét, mega OATS (osteochondral autograft transfer system) technikával ültettük be a relatíve nagy átmérőjú mozaikszerű grafto(ka)t, amelye(ke)t így press fit módon tudtunk rögzíteni (1. ábra). Ehhez a technikához specifikus múszerkészletet használtunk. Amennyiben a femur condylus széle is érintett volt, vagy boka-, illetve radiocarpalis ízületben végeztünk átültetést, úgy az átültetett szövetet valamilyen fémanyaggal rögzítettük, és az oltvány kialakítása szabad kézzel történt (2. ábra).

Az első 2 transzplantációnkhoz „élő donort", az azt követő 17 alkalommal cadaver donort használtunk. Betegeink utánkövetéséhez fizikális vizsgálatot, képalkotó vizsgálatokat (röntgen és MRI) és - a radiocarpalis transzplantációkat kivéve - klinikai score-okat (módosított HSS score, Cincinatti score, illetve AOFAS score és Hannover score) is használtunk. A betegek utánkövetési ideje e cikk megírásakor 2 hónap és 10 év között változik.

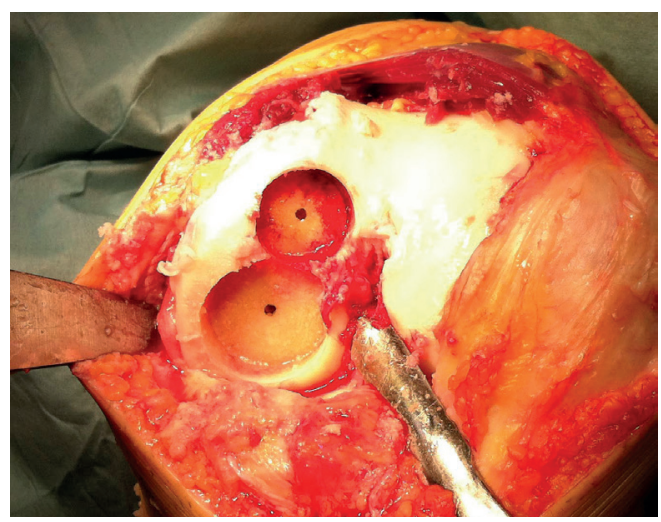

1. bábra

A befogadó hely kitakaritása és előkészitése két nagy átmérőjű mozaikszerü graft beültetésére

(mega OATS technika) 


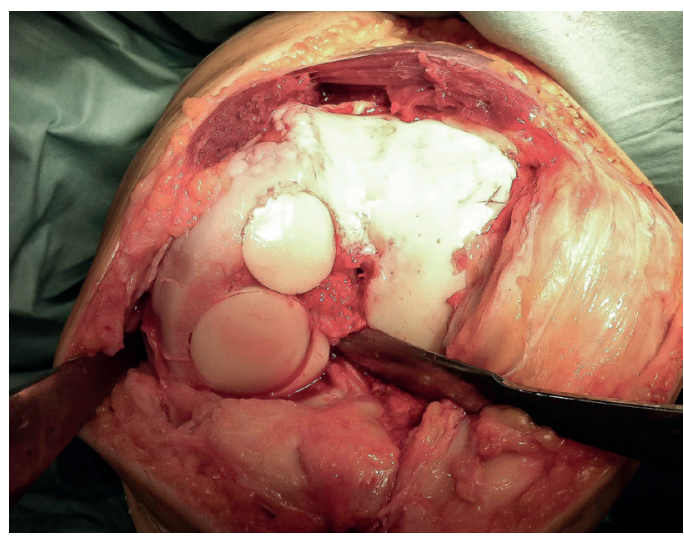

1. c ábra

A femur condylus széle ép, így az oltványok fémanyag nélkül, press fit módon megfelelöen rögzülnek

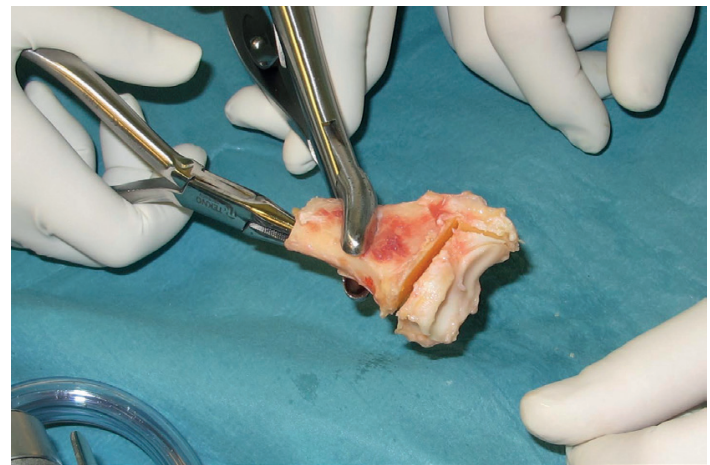

\section{2. a ábra}

Kadáver donorból származó distalis radius vég, amelyből szabad kézzel (oszcillációs fürésszel) reszekáltuk a beültetésre szánt oltványt
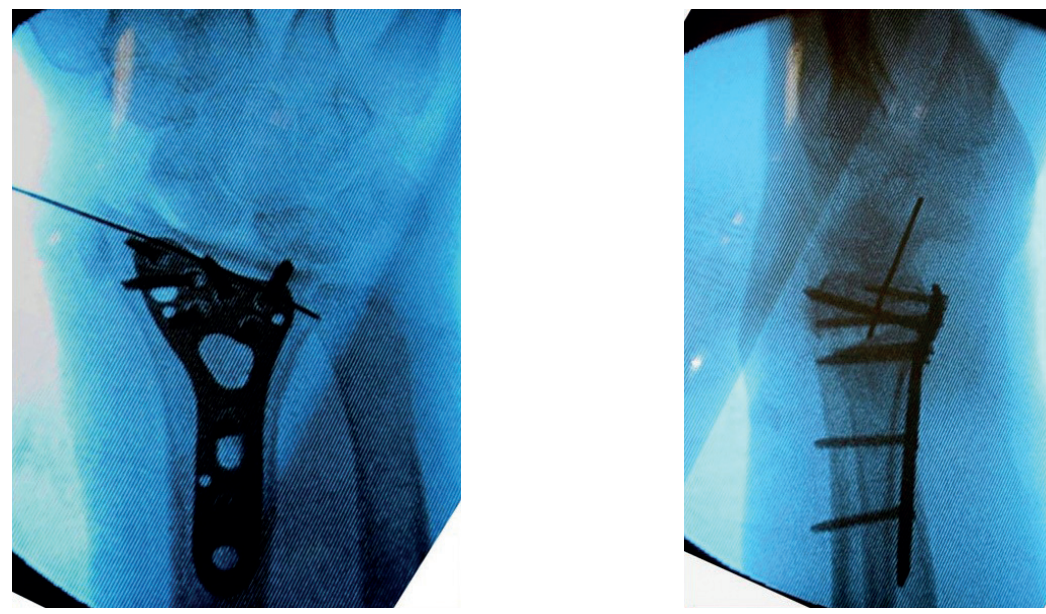

\section{2. $b-c$ ábra}

Ezt a graftot volaris támasztólemezzel és - néhány hétre - 1 db Kirschner dróttal is rögzítettük a recipiens csuklójába (mútét közben készített fotók a C karos átvilágító monitoráról) 


\section{EREDMÉNYEK}

Az eddig elvégzett 19 átültetés során szeptikus szövődményt, thromboemboliás szövődményt, illetve immunológiai okból történő kilökődést nem észleltünk. Átültetéseink kapcsán vírustranszmisszió nem igazolódott.

Öt betegnél kellett reoperációt végeznünk a friss OCA átültetést követően (amely 4 térdízületi és 1 felső ugróízületi OCA átültetést érintett). Ezek közül 1 esetben 19 hónappal a transzplantációt követően térd TEP beültetést végeztünk annál a betegnél, aki autoimmun eredetű, krónikus haemorrhagiás synovitisben szenved. Három esetben több mint fél évvel a beavatkozás után a recipiens érintett ízületi panaszai miatt artroszkópos debridement, szabadtest eltávolítás, részleges fémkivétel történt a graft egy részének sequestrálódása, illetve delaminációja miatt, de mindhárom beteg átültetett graftjának minimum $60 \%$-a funkcionáló csúszófelszín maradt a reoperációt követően is. Az érintett terhelő felszíneken egyidejüleg microfractura-t is végeztünk.

Egy betegnél végeztünk egyéb indikációval artroszkópiát 34 héttel a beültetést követően az érintett térdízületben. Itt a korábban beültetett allograft integrációját figyeltük meg, tapintószondával vizsgálva jó keménységű, kongruens ízfelszínt találtunk (3. ábra).

Egy felső ugróizületi transzplantációnk szövődményeként a hallux hosszú hajlító inának letapadása következett be, emiatt 7 hónappal a transzplantációt követően ínfelszabadítást végeztünk.

Betegeink eddig regisztrált különféle klinikai score-jainak közlésétől a három különböző ízületből származó viszonylag kis esetszám és a betegek utánkövetési idejének különbsége miatt e közleményben eltekintünk, ezek értékelhetőségéhez további adatok gyűjtése szükséges.

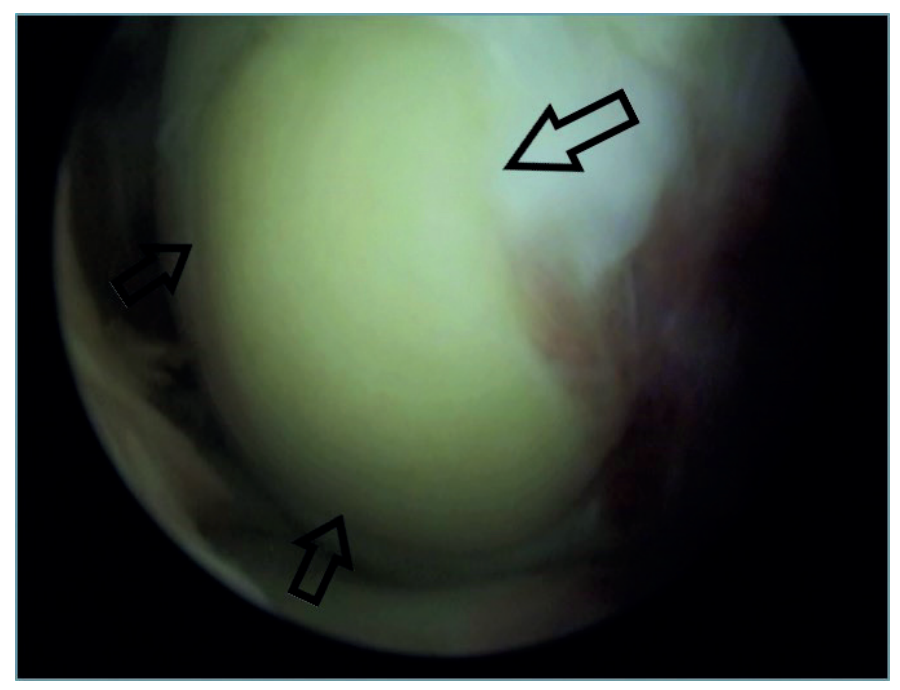

3. ábra

34 héttel a transzplantációt követően térdartroszkópia során tapintószondával vizsgálva jó keménységü, kongruens ízfelszínt találtunk (23 éves nőbeteg, a nyilak a transzplantált támasztószövet szélét jelölik) 


\section{MEGBESZÉLÉS}

Friss OCA beültetéseink kapcsán az északamerikai gyakorlatot vettük alapul, egy számottevő különbséggel: míg az amerikai friss OCA átültetések graft forrása egy erre hitelesített, szigorú protokollokkal dolgozó szövetbank, addig a saját gyakorlatunkban a friss oltványokat az Országos Vérellátó Szolgálat (OVSZ) Szervkoordinációs Irodájával való kollaboráció biztosítja. Ez a gyakorlatban azt jelenti, hogy 2011 óta Budapesten és vonzáskörzetében lévő donációk esetén munkacsoportunk is értesítést kap, és amennyiben a donor megfelelő, lehetőségünk van friss osteochondralis szövet kinyerésére a szükséges ízületből. E kollaboráció megalakulásához szükséges ETT-TUKEB engedély alapján dolgozunk. A Szervkoordinációs Irodával való együttmúködésünk óta körülbelül évi 40-50 donációról kapunk értesítést (közép-magyarországi riasztások), e donorok nagyjából 70\%-a bizonyul friss OCA átültetésre is alkalmas donornak (4. ábra).

Első két térdízületi beültetésünknél - akkor még kadáver donor hiányában - az átültetett szövet „élő donorból” származott. Ez azt jelenti, hogy olyan TEP beültetésre kerülő betegekből nyertük protézisük beültetésekor a transzplantációra szánt osteochondralis szövetet, ahol a preoperatív röntgenvizsgálat és a mútéti makroszkópos lelet alapján ép támasztószövetet találtunk. E betegek preoperatív vírusszűrésen estek át. Tekintettel arra, hogy mind mennyiségi, mind minőségi (élő donorok esetén a transzplantált szövetet degenerációtól többé-kevésbé sújtott ízületből nyertük) szempontból a kadáverból származó OCA kedvezőbb, ma már élő donoros átültetéseket nem végzünk (5. ábra).

$\mathrm{Az}$ észak-amerikai gyakorlatban friss allograft beültetéseket olyan centrumokban végeznek, amelyek megfelelően felszerelt és szigorú protokollokkal dolgozó szövetbankokkal kollaborálnak. A graftokat olyan 15 és 40 év közötti donorokból nyerik, akiknél a porcfelszín makroszkóposan épnek látszik (1). A graftvétel aszeptikus körülmények között zajlik, a meleg ischaemiás időszak minimalizálása mellett. A kinyert oltványokat legtöbbször 4 Celsius fokon, hűtve tárolják (jelentek meg közlemények 37 Celsius fokos tárolásról is) (22). Több tanulmány számol be a temperált graftok különféle
- aminosavakat, glukózt, és szervetlen sókat tartalmazó - tápoldatokban történő tárolásáról, ami a chondrocyták túlélésére és a szerkezeti integritás megtartására jó hatással van. Ezek a tanulmányok azt mutatják, hogy sejtek denzitása, életképessége és metabolikus aktivitása a tárolás kezdetétől számítva 14 napig változatlannak tekinthető, míg a hyalin-mátrix 28 napig többé-kevésbé intakt marad, degenerálódása csak ezután válik szignifikánssá $(2,26)$. E cikkek azt sugallják, hogy a friss OCA-k akár 4 hétig is eltárolhatóak lehetnének, az empirikus gyakorlat azonban a tengerentúlon az, hogy ezek az oltványok 7 napon belül felhasználásra kerülnek (9).

A fentiekre tekintettel saját gyakorlatunkban törekedtünk az átültetési idő minimalizálására, az amerikai gyakorlatnál is rövidebb transzplantációs idő elérésére. Emiatt ultra friss (24-48 órán belüli) transzplantációkat végeztünk azzal a céllal, hogy a lehető legtöbb chondrocyta túlélését biztosítsuk az átültetett szövetben. A tengerentúli donor elérhetőségi gyakorlattól eltérően saját gyakorlatunkban nem szövetbank biztosítja a transzplantációhoz szükséges friss allograftot, hanem a Szervkoordinációs Iroda, és a kinyert támasztószövet minimális tárolási időt követően kerül beültetésre. A szükséges előzetes vírusszűrést az OVSZ elvégzi, negatív vírusszúréssel rendelkező kivizsgált donor esetén történik csak donáció, amelyről a kiszálló team hivatalos igazolást kap. A szövetkivételeket saját magunk végeztük, a felajánló intézmény mútőjében, a Szervkoordinációs Iroda telefonos értesítését követően. Minden szövetkivételünkről mütéti leírást készítünk, amelyet a Szervkoordinációs Iroda archivál.

E gyakorlat kedvező hatással van a chondrocyta túlélésre, ugyanakkor komoly logisztikai kihívást jelent mind a szövetkivevő team, mind a beültetést végző sebész, és nem utolsósorban a transzplantációra váró beteg számára is. Transzplantációra váró betegeinket az allograft beültetés indikációjakor várólistára helyeztük, és tájékoztattuk őket arról, hogy egy esetleges donációs riasztáskor telefonon értesítjük őket, és ezt követően egy 24-48 órán belüli transzplantációhoz kell majd alkalmazkodniuk. A betegek részéről e gyakorlat kapcsán jó compliance-szel szembesültünk, elenyésző volt azon betegek száma, akik a telefonos 
értesítéskor a mútétet nem vállalták. Várólistánkon a betegek érintett ízülete, lakcíme és telefonos elérhetősége mellett az alábbiakat rögzítettük: életkor, magasság, testsúly, lábméret. Egy donációs riasztás esetén a Szervkoordinációs Iroda munkatársa tájékoztatást ad a donor életkoráról, fizikai paramétereiről. A várólistáról a beteg kiválasztását a felvett adatok alapján, fizikai hasonlóság szerint végezzük.

Szervezési szempontból saját gyakorlatunk (a „váratlan mútét” beillesztése a napi elektív mútéti programba, esetleg ügyeleti időben való elvégzése, az ország potenciálisan távoli pontján élő várólistás beteg 1-2 napon belüli mútétre való behívása, előkészítése stb.) a szövetbanki háttérrel és hosszabb időablakkal dolgozó amerikai centrumok rutinjához képest nehezebben megoldható. Ez a különbség tükröződik abban is, hogy a „klasszikus indikációt” jelentő mély, nagy kiterjedésű defektusok mellett e nyugati centrumok már felszínesebb, kisebb kiterjedésú laesiók esetén is beültetnek friss allograftot, azaz ma már az eljárás kiterjesztett indikációjú alkalmazása is jellemző.

A beültetés technikáját illetően kedvező körülménynek számít, ha van olyan instrumentárium, ami az operatőrt segíti, a beültetést valamelyest standardizálja. Ez az OCA átültetéseknél saját gyakorlatunkban a mega OATS technikában nyilvánul meg, amely nagyméretű mozaikszerű graftok kialakítását és beültetését támogatja. Sajnos ezt a technikát csak olyan térdízületi beültetéseknél tudjuk használni, ahol a defektust ép condylus állomány veszi körül (1. ábra). Amennyiben a defektus a femur condylus szélét is érinti, vagy egyéb ízületben operálunk, a graftokat jelenlegi lehetőségeink mellett szabad kézzel kell kialakítanunk (ráadásul bokában és csuklóban olykor bipoláris, szembe néző congruens ízfelszíneket), és valamilyen fémanyaggal is rögzítenünk kell őket a megfelelően kialakított befogadó helyre, speciális műszerkészlet nélkül. Ez igen nagy sebészi rutint igényel (6. ábra). Emiatt jelenleg olyan műszerkészlet beszerzésén/fejlesztésén dolgozunk, mely segíti a friss OCA átültetés speciális elhelyezkedésű, illetve felszínesebb (héjszerű) beültetését.

Bármelyik technikát választjuk is, a graftok csontos bázisát a beültetést megelőzően nagy nyomású fiziológiás sóoldattal (pl. pulsedlavage vagy jet-lavage alkalmazásával) alaposan kimossuk. Erre azért van szükség, hogy a csontgerendák között esetlegesen visszamaradt, immunválaszt kiváltani képes, donortól származó vérsejtek, csontvelői elemek számát minimálisra csökkentsük.

Transzplantált betegeink rehabilitációja egyénre szabottan alakult, köszönhetően az átültetések eltérő lokalizációinak és az átültetett oltványok különböző méretének. Az egyik legfontosabb szempontunk az volt az utókezelés során, hogy minél masszívabb defektust pótoltunk, a tehermentesítés ideje annál hosszabb legyen az átütetést követően. Ugyanakkor az érintett ízület azonnali mozgatására törekedtünk a mútét után, stimulálva ezzel az átültetett támasztószövet integrációját a befogadó helyre (7. ábra).

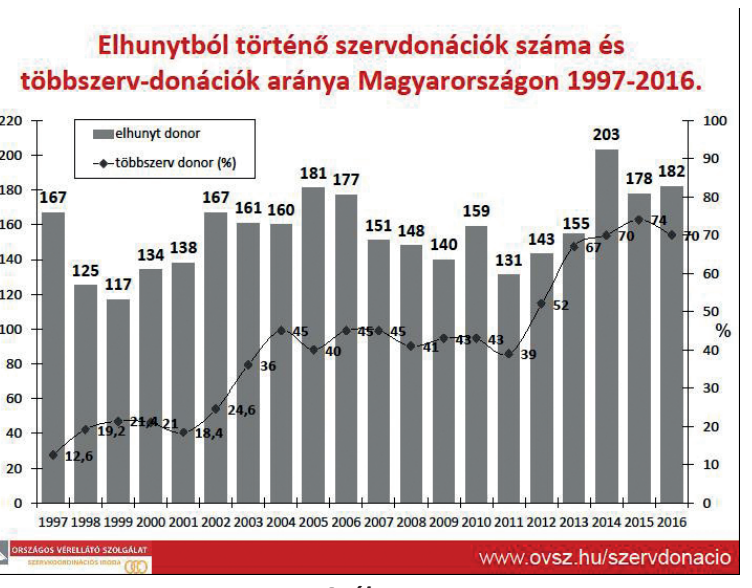

4. ábra

Az elmúlt 20 év szervdonációinak számszerü alakulása Magyarországon (forrás: www.ovsz.hu) 


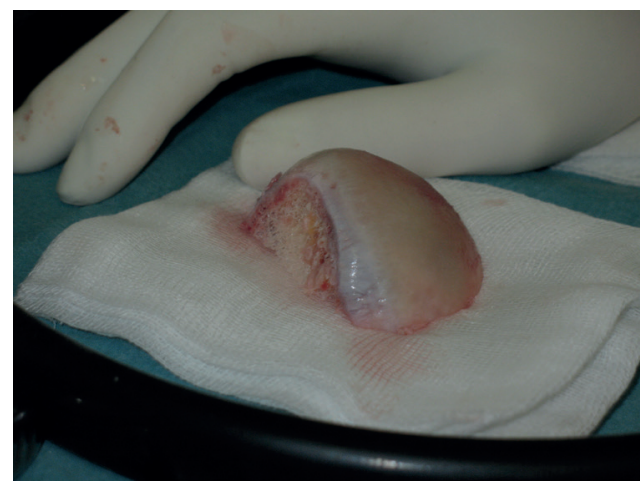

5. a ábra

Élő donor combfejéből készített, beültetésre szánt oltvány

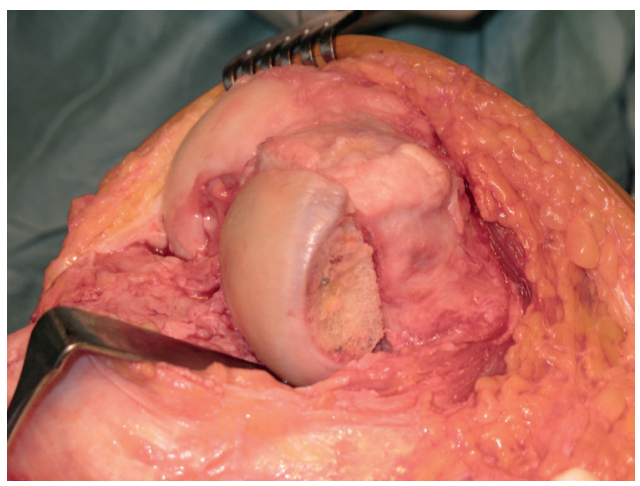

5. $b$ ábra

Az oltványt 2 db tüződrót rögzíti ideiglenesen a befogadó helyre

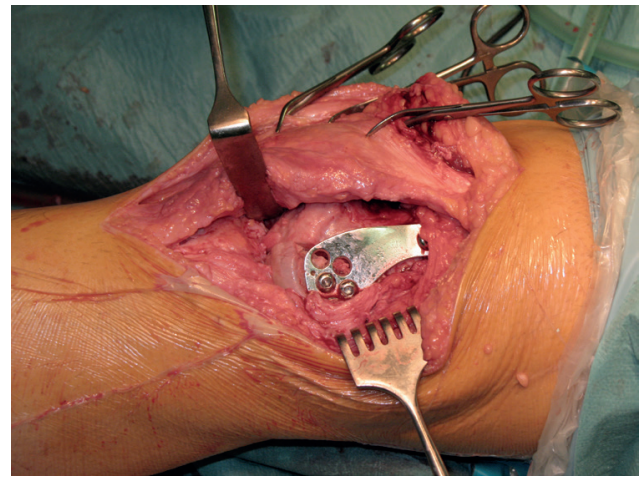

5. c ábra

A graft végleges rögzítése támasztólemezzel

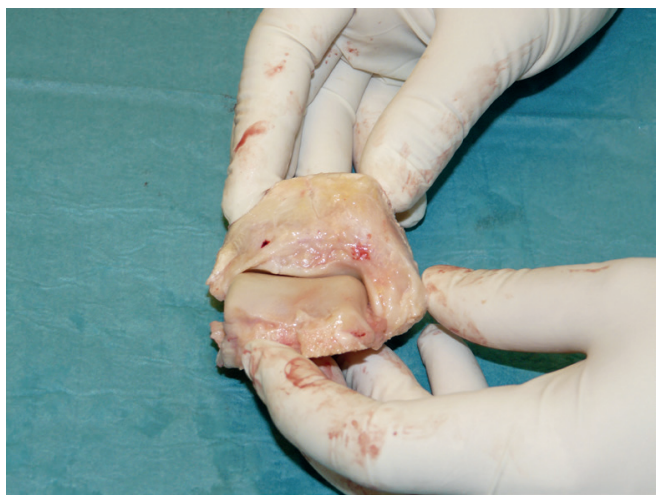

6. a ábra

A donáció során eltávolított donor felső ugróizület

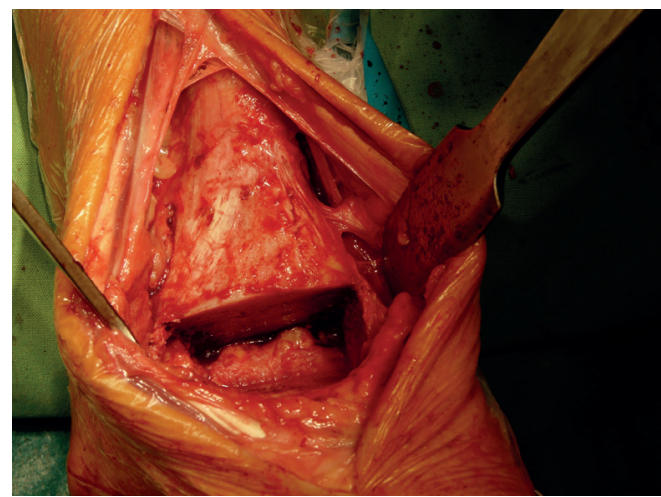

\section{6. b ábra}

A destruált felső ugróizület ízfelszínek eltávolítását követően így néz ki a recipiens oldali befogadó hely 


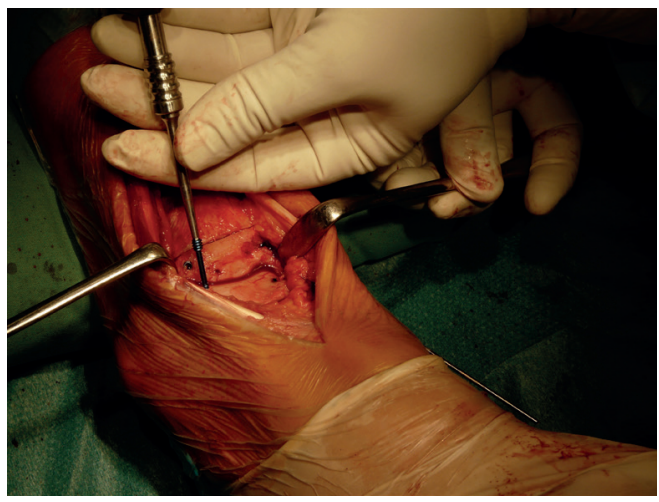

6. c ábra

A szabad kézzel befaragott bipoláris allograftot ízfelszín alá süllyesztett titán csavarokkal és 1 db Kirschner dróttal rögzítettük.
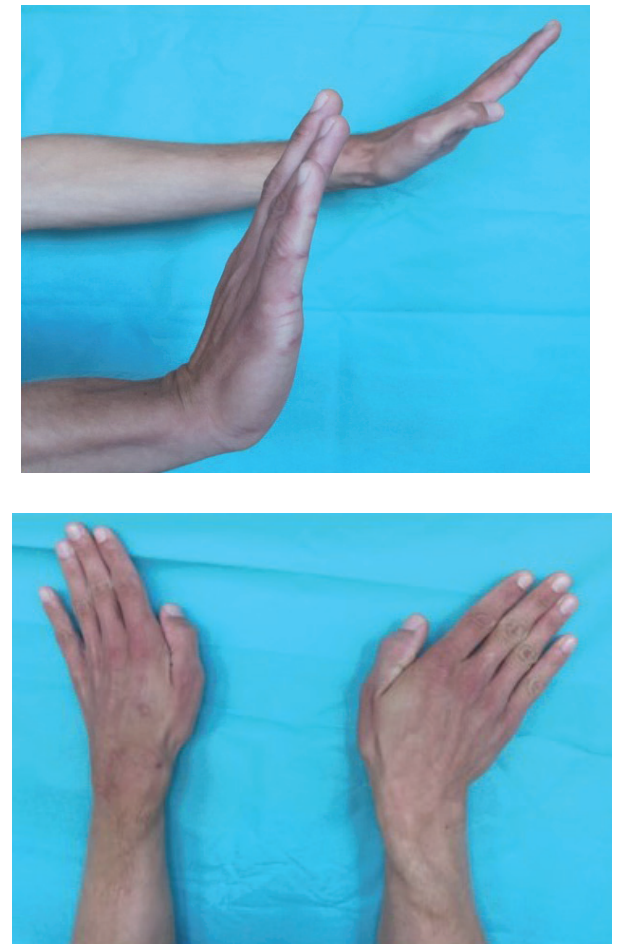

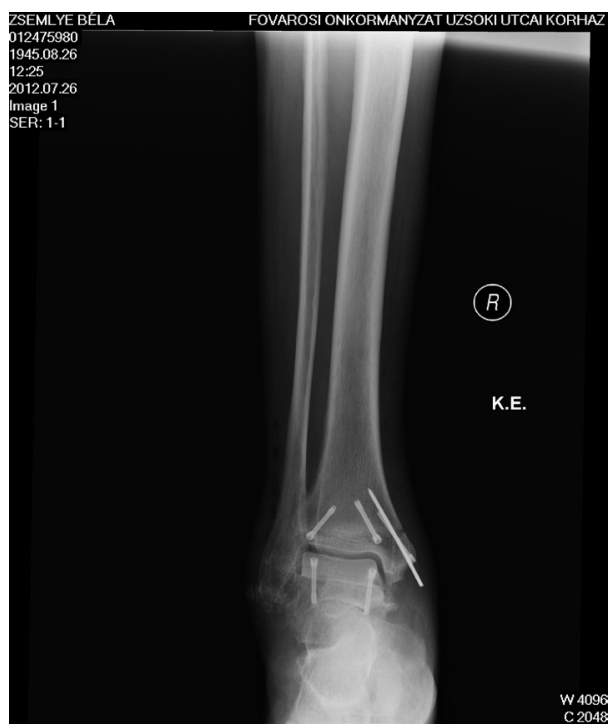

6. d ábra

Posztoperativ röntgenfelvétel. A transzplantált oltványokat csavarok és átmenetileg 1 db Kirschner drót is rögzíti
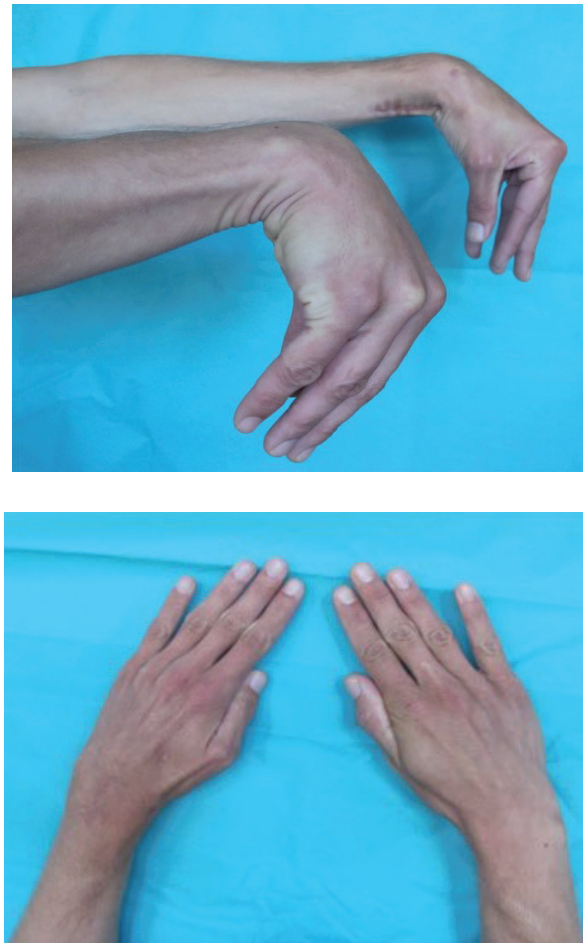

7. $a-d$ ábra

Bal oldali radiocarpalis transzplantáció funkcionális eredménye 4 hónappal a beültetést követően 


\section{KÖVETKEZTETÉSEK}

Az elmúlt 10 év alatt elvégzett transzplantációink azt bizonyítják, hogy az ultra friss OCA átültetés megfelelő terápiás lehetőség a masszív osteochondralis defektusok kezelésére, különösen fiatal életkorban. Az OVSZ Szervkoordinációs Irodájával való, 2011 óta tartó együttmúködésünk jelenlegi, a módszer klasszikus indikációjú alkalmazása mellett megfelelő donorszámot biztosít, sőt ez a szám az allograftok kiterjedtebb klinikai alkalmazását is lehetővé tehetné (akár felszínesebb, kisebb méretű defektusok sebészi kezelését is). Mindazonáltal, az eljárás komoly logisztikai feladatot jelent: egy ultra friss beültetéshez való alkalmazkodás, azaz az egész procedúra 24-48 órán belül való kivitelezése mind a donációban résztvevő, graftot kivevő és beszállító team, mind a beültetést végző orvos, az érintett mútő, illetve napi elektív mútéti program, mind a várólistán lévő, értesítést váró beteg részére komoly megterhelést jelent. Emellett jelenleg mútéttechnikailag is nagyon igényes az eljárás. Ez nehezíti a technika szélesebb körű hazai alkalmazását, ugyanakkor a viszonylag nagyszámú magyarországi donáció nyújtotta lehetőség perspektívát jelent a jövőre nézve a friss OCA-k vonatkozásában.

\section{IRODALOM}

1. American Association of Tissue Banks.: Standards for tissue banking. Arlington, VA: American Association of Tissue Banks. 1987.

2. Ball S. T., Amiel D., Williams S. K., Tontz W., Chen A. C., Sah R. L., Bugbee W. D.: The effects of storage on fresh human osteochondral allografts. Clin. Orthop. Relat. Res. 2004. 418: $246-252$. https://doi.org/10.1097/00003086-200401000-00043

3. Bugbee W. D., Convery F. R.: Osteochondral allograft transplantation. Clin. Sports Med. 1999. 18. (1): 67-75. https://doi.org/10.1016/S0278-5919(05)70130-7

4. Chapovsky F., Kelly J. D. 4th: Osteochondral allograft transplantation for treatment of glenohumeral instability. Arthroscopy. 2005. 21. (8): 1007. https://doi.org/10.1016/j.arthro.2005.04.005

5. Csönge L., Bravo D., Newman-Gage H., Rigley T., Conrad E. U., Bakay A., Strong D. M., Pellet S.: Banking of osteochondral allografts, Part II. Preservation of chondrocyte viability during long-term storage. Cell Tissue Bank. 2002. 3. (3): $161-168$. https://doi.org/10.1023/A:1023687419152

6. Czitrom A. A., Langer F., McKee N., Gross A. E.: Bone and cartilage allotransplantation. A review of 14 years of research and clinical studies. Clin. Orthop. Relat. Res. 1986. 208: 141-145.

7. Enneking W. F., Campanacci D. A.: Retrieved human allografts: a clinicopathological study. J. Bone Joint Surg. Am. 2001. 83-A. (7): 971-986. https://doi.org/10.2106/00004623-200107000-00001

8. Ghazavi M. T., Pritzker K. P., Davis A. M., Gross A. E.: Fresh osteochondral allografts for post-traumatic osteochondral defects of the knee. J. Bone. Joint. Surg. Br. 1997. 79. (6): 1008-1013. https://doi.org/10.1302/0301-620X.79B6.7534

9. Görtz S., Bugbee W. D.: Allografts in articular cartilage. J. Bone Joint Surg. Am. 2006. 88. (6): $1374-1384$. https://doi.org/10.2106/00004623-200606000-00030

10. Gross A. E., Agnidis Z., Hutchison C. R.: Osteochondral defects of the talus treated with fresh osteochondral allograft transplantation. Foot Ankle Int. 2001. 22. (5): 385-391. https://doi.org/10.1177/107110070102200505

11. Gross A. E., Kim W., Las Heras F., Backstein D., Safir O., Pritzker K. P.:Fresh osteochondral allografts for posttraumatic knee defects: long-term followup. Clin. Orthop. Relat. Res. 2008. 466. (8): $1863-1870$. https://doi.org/10.1007/s11999-008-0282-8

12. Jomha N. M., Lavoie G., Muldrew K., Schachar N. S., McGann L. E.: Cryopreservation of intact human articular cartilage. J. Orthop. Res. 2002. 20. (6): 1253-1255. https://doi.org/10.1016/S0736-0266(02)00061-X

13. Kandel R. A., Gross A. E., Ganel A., McDermott A. G., Langer F., Pritzker K. P.: Histopathology of failed osteoarticular shell allografts. Clin. Orthop. Relat. Res. 1985. 197: 103-110. https://doi.org/10.1097/00003086-198507000-00012

14. Langer F., Gross A. E.: Immunogenicity of allograft articular cartilage. J. Bone Joint Surg. Am. 1974. 56. (2): $297-304$. https://doi.org/10.2106/00004623-197456020-00007

15. Lexer E.: The use of free osteoplasty together with trials on arthrodesis and joint transplantation. Archivfürklinische Chirurgie. 1908. 86. (4): 939-954.

16. Lightfoot A., Martin J., Amendola A.: Fluorescent viability stains overestimate chondrocyte viability in osteoarticular allografts. Am. J. Sports Med. 2007. 35. (11): 1817-1823. https://doi.org/10.1177/0363546507305010

17. Malinin T. I., Wagner J. L., Pita J. C., Lo H.: Hypothermic storage and cryopreservation of cartilage. An experimental study. Clin. Orthop. Relat. Res. 1985. 197: 15-26.

18. Meyers M. H.: Resurfacing of the femoral head with fresh osteochondral allografts. Long-term results. Clin. Orthop. Relat. Res. 1985. 197: 111-114. https://doi.org/10.1097/00003086-198507000-00013

19. Oakeshott R. D., Farine I., Pritzker K. P., Langer F., Gross A. E.: A clinical and histologic analysis of failed fresh osteochondral allografts. Clin. Orthop. Relat. Res. 1988. 233: 283-294. https://doi.org/10.1097/00003086-198808000-00035 
20. Ohlendorf C., Tomford W. W., Mankin H. J.: Chondrocyte survival in cryopreserved osteochondral articular cartilage. J. Orthop. Res. 1996. 14. (3): 413-416. https://doi.org/10.1002/ior.1100140311

21. Schachar N. S., Novak K., Hurtig M., Muldrew K., McPherson R., Wohl G., Zernicke R. F., McGann L. E.: Transplantation of cryopreserved osteochondral dowel allografts for repair of focal articular defects in an ovine model. J. Orthop. Res. 1989. 17. (6): 909-919. https://doi.org/10.1002/jor.1100170616

22. Schaek L. M., Clausen J. D., Noack S., Harb A., Krettek C., Neunaber C.: Nichtkryokonservierende Lagerungsstrategien für frische osteochondrale Allografts. Unfallchirurg. 2017. 120. (11): 918-926. https://doi.org/10.1007/s00113-017-0418-y

23. Shasha N., Krywulak S., Backstein D., Pressman A., Gross A. E.: Long-term follow-up of fresh tibial osteochondral allografts for failed tibial plateau fractures. J. Bone Joint Surg. Am. 2003. 85-A. (Suppl. 2): 33-39. https://doi.org/10.2106/00004623-200300002-00005

24. Strong D. M., Friedlaender G. E., Tomford W. W., Springfield D. S., Shives T. C., Burchardt H., Enneking W. F., Mankin H. J.: Immunologic responses in human recipients of osseous and osteochondral allografts. Clin. Orthop. Relat. Res. 1996. 326: 107-114. https://doi.org/10.1097/00003086-199605000-00013

25. Tomford W. W.: Transmission of disease through transplantation of musculoskeletal allografts. J. Bone. Joint. Surg. Am. 1995. 77. (11): 1742-1754. https://doi.org/10.2106/00004623-199511000-00017

26. Williams R. J. 3rd., Dreese J. C., Chen C. T.: Chondrocyte survival and material properties of hypothermically stored cartilage: an evaluation of tissue used for osteochondral allograft transplantation. Am. J. Sports Med. 2004. 32. (1): 132139. https://doi.org/10.1177/0095399703258733

27. Williams S. K., Amiel D., Ball S. T., Allen R. T., Tontz W. L. Jr., Emmerson B. C., Badlani N. M., Emery S. C., Haghighi P., Bugbee W. D.: Analysis of cartilage tissue on a cellular level in fresh osteochondral allograft retrievals. Am. J. Sports Med. 2007.35. (12): 2022-2032. https://doi.org/10.1177/0363546507305017

28. Wingenfeld C., Egli R. J., Hempfing A., Ganz R., Leunig M.: Cryopreservation of osteochondral allografts: Dimethyl Sulfoxide promotes angiogenesis and immune tolerance in mice. J. Bone Joint Surg. Am. 2002. 84-A. (8): 1420-1429. https://doi.org/10.2106/00004623-200208000-00018

\section{Dr. Hangody László Rudolf}

Uzsoki Utcai Kórház, Ortopéd-Traumatológiai Osztály

1145 Budapest, Uzsoki u. 29.

E-mail: hangodylaszlo@gmail.com 